\title{
Inhibitory effect of some phytochemicals in the growth of yeasts potentially causing opportunistic infections
}

\author{
Igara O. Lima', Rinalda de Araújo G. Oliveira', Edeltrudes de O. Lima', Evandro L. de Souza², \\ Nilma Porto Farias ${ }^{1}$, Dionezine de Fátima Navarro ${ }^{3}$
}

\author{
'Laboratório de Micologia, Departamento de Ciências Farmacêuticas, Centro de Ciências da Saúde, \\ Universidade Federal da Paraíba, ${ }^{2}$ Departamento de Nutrição, Centro de Ciências da Saúde, \\ Universidade Federal da Paraíba, ${ }^{3}$ Laboratório de Farmacotécnica, Departamento de Ciências Farmacêuticas, \\ Universidade Estadual de Ponta Grossa
}

\begin{abstract}
Opportunistic infections caused by yeasts have been characterized as emerging diseases all over the world and this has caused the search for new products capable of inhibiting the survival of their etiological agents. In this study the sensitivity of some yeast potentially causing infections to $\alpha$-pinene, $\beta$-pinene, citral and eugenol was evaluated. All phytochemicals showed inhibitory action on the assayed yeast strains: Candida. albicans, C. tropicalis, C. guilliermondii, C. stellatoidea, C. krusei, C. parapsilosis and Cryptococcus neoformans, presenting their MIC values in the range of 1 and $4 \%$. The phytochemicals presented effectiveness to provide high fungicide effect in a short time. These data support the possible use of some phytochemicals as useful tools to control the occurrence of opportunistic infections caused by yeasts.
\end{abstract}

\section{Uniterms}

- Phytochemicals

- Yeasts

- Mycoses

- Antiyeast action

\section{INTRODUCTION}

Yeasts are ubiquitous microorganisms dispersed in nature by animals, humans, insects, water and wind, so that some of them when in touch with humans could act as infectious etiological agents (Hazen, 1995). Nowadays, opportunistic mycoses of larger or smaller severity have been characterized as having progressively increasing occurrence all over the world (Meunier et al., 1992).

Candida and Cryptococcus genera have been recognized as main causative agents of opportunistic infections being the skin, digestive and respiratory systems the main way of these microorganisms into the human body
(Edwards, Filler, 1992). Yeasts with the capacity to cause infections present several virulence attributes: i) phenotypic variability; ii) adherence capability to the host tissues, and iii) enzymes and toxins synthesis (Gompertz, 2002). Opportunistic mycoses have attacked mainly immunological suppressed people being this suppression caused mainly by degenerative diseases (e.g. cancer, diabetes), immunological suppressors or antibiotic therapy use (Anaissie, 1992; Dupont et al., 1992).

Wide and indiscriminate use of antibiotics has been an ultimate pressure factor for the emergence of infectious diseases of difficult control and it has been reported as a phenomenon related to the development of microorganisms 
more and more resistant to conventional antibiotics applied in the antimicrobial therapy (Akinpelu, 2001). This worring reality has led to a steady search for new and effective antimicrobial agents (Marino et al., 2001). Systematic screening of the biological interaction between microorganisms and plant products has been valuable source of several compounds able to control the survival of pathogen microorganisms (Arora, 1999; Cowan, 1999). This study was led with the purpose to analyze the sensitivity profile of yeasts potentilly causing infection to some phytochemicals.

\section{MATERIAL AND METHODS}

\section{Yeast strains}

Candida albicans ATCC-76615, C. tropicalis MD-40, C. parapsilosis ME-02, C. stellatoidea LM41V, C. guilliermondii LM-67, C. krusei FCF-281 and Criptococcus neoformans JSS-07 strains were used as test microorganisms. These strains were supplied by Laboratory of Mycology, Pharmaceutical Sciences Department, Health Sciences Center, Federal University of Paraíba, Brazil.

\section{Phytochemicals}

Citral, eugenol, $\alpha$-pinene and $\beta$-pinene had their antiyeast activity evaluated and were supplied by Pharmaceutical Science Department, State University of Ponta Grossa, Paraná, Brazil. Molecular structures of the phytochemicals are shown in Figure 1.

\section{Antiyeast activity screening}

Solid medium diffusion technique using filter paper discs was used to carry out the antiyeast activity screening. In sterile Sabouraud agar petri dishes $1 \mathrm{~mL}$ of the yeast suspension prepared in sterile physiological saline solution $\left(10^{6} \mathrm{CFU} / \mathrm{mL}\right.$, according to $0.5 \mathrm{McF}$ arland scale tube) was uniformly inoculated (Odds, 1989). Afterwards, sterile filter paper disc (Whatman n. 1, diameter $6 \mathrm{~mm}$ ) soaked with $20 \mu \mathrm{L}$ of the phytochemical was put on the center of sterile Sabouraud agar petri dish (Hadaceck, Greger, 2000). Incubation period was of 48 hours at $37^{\circ} \mathrm{C}$. At the end of the incubation period, the diameters of the inhibition halos were measured using calipers and the results expressed in millimeters, so that when the observed halo presented a diameter equal or higher than $10 \mathrm{~mm}$ it was considered positive to antiyeast activity (Lima, 1993). Ketoconazole $(50 \mu \mathrm{g} / \mathrm{mL})$ was used as control for the

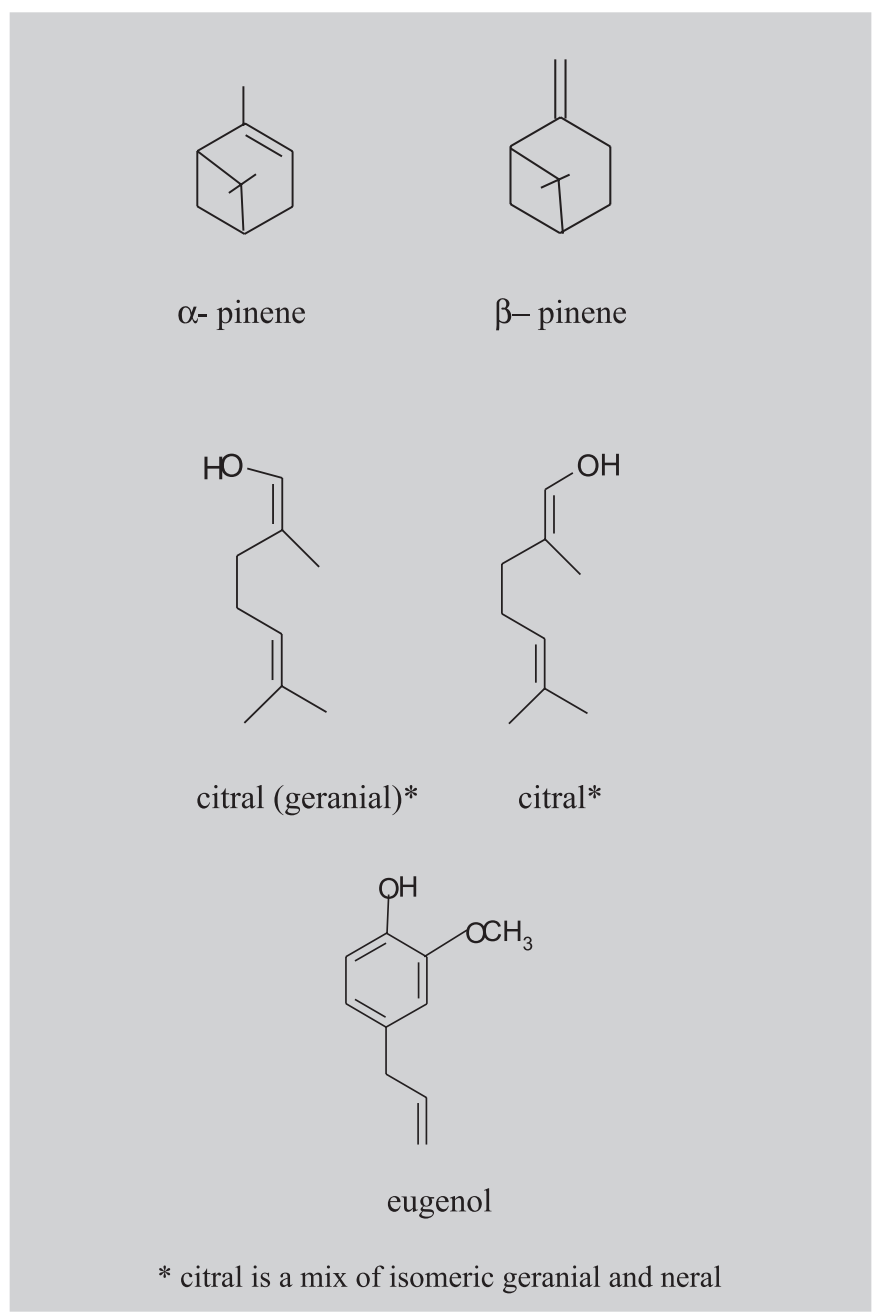

FIGURE 1 - Molecular structures of phytochemicals used in the antiyeast assays.

antiyeast activity by solid medium diffusion technique using filter paper discs.

\section{Determination of the Minimum Inhibitory Concentration (MIC)}

A solid medium diffusion technique using wells in dishes was used to determine the MIC of the phytochemicals that presented positive antiyeast activity in the screening assay. A suspension of $1 \mathrm{~mL}$ of the yeast $\left(10^{6} \mathrm{UFC} / \mathrm{mL}\right)$ was uniformly spread in sterile Sabouraud agar petri dishes. After the inoculum absorption by Sabouraud agar, wells were made using sterile glass stems (diameter $6 \mathrm{~mm}$ ) where it was put $50 \mu \mathrm{L}$ of solutions adjusted for having phytochemicals final concentrations of 8.0, 4.0, 2.0, 1.0 and $0.5 \%$ (Alegrini, 1973). Incubation period was 48 hours at $37^{\circ} \mathrm{C}$. At the end of the incubation period the inhibition halos were measured using the same 
procedure cited in the screening assay. The lower concentration able to develop inhibition with diameter of halos equal or higher than $10 \mathrm{~mm}$ was considered as MIC.

The screening and MIC determination procedures were carried out in duplicate and the results were expressed using the average values obtained in two parallel assays.

\section{Activity on the yeast viable cells number}

The activity on the yeast viable cells number was studied for the MIC of each phytochemical. Initially, $1 \mathrm{~mL}$ of the yeast suspension $\left(10^{5} \mathrm{UFC} / \mathrm{mL}\right)$ was added to $4 \mathrm{~mL}$ of double strength Sabouraud broth. Afterwards, $5 \mathrm{~mL}$ of the phytochemical solution were added to it and shaken for 5 minutes using vortex followed by incubation at $37^{\circ} \mathrm{C}$ $\left( \pm 1^{\circ} \mathrm{C}\right)$. On times $0,1,2,3$, and 4 hours post incubation, $10 \mu \mathrm{L}$ of the mixture was uniformly spread on sterile Sabouraud agar Petri dishes and incubated for 48 hours at $37^{\circ} \mathrm{C}$. At the end of the incubation period the viable cells count was carried out. Control assay was performed using replacement of the phytochemicals solution for sterile distilled water (Arora, Kaur, 1999). Each experiment was performed in duplicate and the results, average of two repetitions, were expressed in log units (log Colony Forming Units $/ \mathrm{mL}-\log \mathrm{CFU} / \mathrm{mL}$ ).

\section{RESULTS AND DISCUSSION}

Table I shows the results obtained in the screening of the inhibitory activity of the phytochemicals on the growth of yeasts potentially causing infections. Phytochemicals presented antiyeast effectiveness in all assayed yeasts showing halos of inhibition whose diameter oscillated between 10 and $30 \mathrm{~mm}$. Larger inhibition halos $(30 \mathrm{~mm})$ were found in the interactions involving $\alpha$-pinene $\mathrm{x} C$. albicans, $\alpha$-pinene x C. krusei, $\alpha$-pinene x $C$. parapsilosis and $\alpha$-pinene x C. guilliermondii. C. krusei and $C$. albicans were the most sensitive yeasts showing halos of inhibition whose diameter averaged out 24.3 and $23.8 \mathrm{~mm}$, respectively. On the other hand, C. tropicalis was the least sensitive strain with inhibition halos whose diameter averaged $17 \mathrm{~mm}$.

Table II shows the MIC values found for each phytochemical. Eugenol presented the smallest MIC, 1\%, forming in this concentration inhibition halos diameter between 11 (on C. guilliemondii) and $15 \mathrm{~mm}$ (on $C$. krusei). $\alpha$-Pinene and citral showed antiyeast activity until concentration $2 \%$, being $\alpha$-pinene active against a higher number of yeasts strains. $\beta$-Pinene presented the highest MIC, 4\%, showing higher inhibitory effect on $C$. neoformans.

The assays regarding the effect of the phytochemicals on the yeasts viable cells number showed prominent fungicide effect. $\alpha$-Pinene $(2 \%)$ decreased the C. krusei viable cells number on time 01 hour in $2.0 \mathrm{log}$ cycles when compared with the count obtained to the control experiment at the same time. On time 02 hours $\alpha$-pinene showed intense fungicide effect providing total elimination of $C$. crusei viable cells. The most intense fungicide activity was exerted by citral $(2 \%)$ on $C$. neoformans providing total elimination of viable cells already on time 1 hour. $\beta$-Pinene $(4 \%)$ presented fungistatic effect on $C$. albicans until time 01 hour, however after 02 hours showed strong fungicide effect characterized for total elimination of viable cells. Similar behavior occurred to the interactions involving C. krusei $\mathrm{x}$ citral (2\%) and C. tropicalis x eugenol (1\%)

Some phytochemicals have been studied regarding their antimicrobial potential on bacterial and fungi species (Karapnar, Aktug, 1987; Karapnar, 1990; Delaquis, Mazza, 1995; Helander et al., 1998; Nascimento et al., 2000).

TABLE I - Inhibitory activity of phytochemicals in absolute concentration on yeasts potentially causing opportunistic infections (screening)*

\begin{tabular}{lccccc}
\hline \multirow{2}{*}{ Yeasts } & \multicolumn{4}{c}{ Phytochemicals } & \\
\cline { 2 - 4 } & $\boldsymbol{\alpha - P i n e n e}$ & $\boldsymbol{\beta}$-Pinene & Citral & Eugenol & Control** $^{*}$ \\
\hline C. albicans & 30 & 20 & 20 & 25 & 25 \\
C. krusei & 30 & 21 & 20 & 26 & 25 \\
C. tropicalis & 15 & 10 & 10 & 24 & 26 \\
C. stellatoidea & 25 & 19 & 20 & 25 & 23 \\
C. parapsilosis & 30 & 10 & 15 & 26 & 25 \\
C. guilliermondii & 30 & 20 & 17 & 25 & 27 \\
C. neoformans & 25 & 25 & 25 & 25 & 25 \\
\hline
\end{tabular}

* results expressed in diameter of inhibition halos $(\mathrm{mm}) ; * *$ control: ketoconazole $(50 \mu \mathrm{g} / \mathrm{mL})$ 
TABLE II - Inhibitory activity of the phytochemicals MIC on opportunistic infections potentially causing yeasts*

\begin{tabular}{lcccc}
\hline Yeasts & \multicolumn{4}{c}{ Phytochemicals } \\
\cline { 2 - 5 } & $\boldsymbol{\alpha}$-Pinene $\mathbf{2 \%}$ & $\boldsymbol{\beta}$-Pinene $\mathbf{4 \%}$ & Citral 2\% & Eugenol 1\% \\
\hline C. albicans & 12 & 10 & - & 14 \\
C. krusei & 20 & 18 & 10 & 15 \\
C. tropicalis & 14 & 15 & - & 12 \\
C. stellatoidea & - & - & 12 & - \\
C. parapsilosis & - & 17 & - & 12 \\
C. guilliermondii & 11 & - & - & 11 \\
C. neoformans & 15 & 15 & 17 & 14 \\
\hline
\end{tabular}

* results presented in inhibition halos diameter $(\mathrm{mm})$; - : any sensitivity to the concentration.

However, it is still considered small the number of scientific reports emphasizing the antimicrobial activity of phytochemicals. Most of the researches have evaluated the antimicrobial potential of essential oils and/or plant extracts (Delaquis, Mazza, 1995; Helander et al., 1998).

Phytochemicals are small organic biomolecules designated as naturally occurring antibiotics (Brull, Coote, 1999). These compounds are generally hydrophobic and could have their antimicrobial action exerted by membrane perturbing or even membrane rupturing (Helander et al., 1998). In general, antifungal action of plant compounds involves cytoplasm granulation, cytoplasmic membrane rupturing and inactivation and/or synthesis inhibition of intercellular and extracellular enzymes (Stangarlin et al., 1999).

The results obtained in this study show the immense pharmacological potential of plant products, particularly, the antiyeast potential of some phytochemicals. Citral, eugenol, $\alpha$-pinene and $\beta$-pinene could appear as promising compounds to be inserted in pharmaceutical formulations applied to control the survival and dissemination of etiological agents of superficial or systemic opportunistic mycoses. Moreover, the results of this study show the necessity of accomplishment of researches addressed to the evaluation of antimicrobial properties of several phytochemicals in different pathogenic microorganisms.

\section{RESUMO}

\section{Efeito Inibitório de alguns fitoconstituintes sobre o crescimento de leveduras potencialmente causadoras de infecções oportunistas}

Infecções oportunistas causadas por leveduras têm sido caracterizadas como doenças emergentes em todo o mundo e este fenômeno tem levado ao desenvolvimento de novos produtos capazes de inibir a sobrevivência de seus agentes etiológicos. Este estudo ava- liou o perfil de sensibilidade de leveduras potencialmente causadoras de infecções oportunistas frente aos fitoconstituintes $\alpha$-pineno, $\beta$-pineno, citral e eugenol. Todos os fitoconstituintes mostraram ação inibitória sobre as leveduras ensaiadas, as quais foram Candida albicans, C. tropicalis, C. guilliermondii, C. stellatoidea, C. krusei, C. parapsilosis e Cryptococcus neoformans, tendo valores de CIM oscilando entre 1 e 4\%. Os fitoconstituintes mostraram eficácia para provocar um alto efeito fungicida em curto tempo de ação. Estes dados subsidiam o possivel uso de alguns fitoconstituintes como ferramentas úteis para controlar a ocorrência de infecções oportunistas causadas por leveduras.

UNITERMOS: Fitoconstituintes. Leveduras. Micoses. Ação antileveduriforme.

\section{REFERENCES}

AKIMPELU, D.A. Antimicrobial activity of Anacardium occidentale Bark. Fitoterapia, Milano, v. 72, p. 286-287, 2001.

ALLEGRINI, J.; BOUCHBERG, M.S.; MAILOLS, H. Émulsiond d'huilles essentielles frabricaton et applications en microbiologie. Soc. Pharm. Montpellier, Montpellier, v. 33, p. 73-86, 1973.

ANAISSIE, E. Opportunistic mycoses in the immunocropromissed host: experience at a Cancer Center and Review. Clin. Infec. Dis., Chicago, v. 14, p. 43-45, 1992.

ARORA, D.S.; KAUR, J. Antimicrobial activity of spices. Int. J. Antim. Agen., New York, v. 12, p. 257-262, 1999. 
BRUL, S.; COOTE, P. Preservative agents in foods: mode of action and microbial resistance mechanisms. Int. J. Food Microbiol., Copenhagen, v. 50, p. 1-17, 1999.

COWAN, A.M. Plant products as antimicrobial agents. Clin. Microbiol. Rev., Chicago, v. 12, p. 564-582, 1999.

DELAQUIS, P.J.; MAZZA, G. Antimicrobial properties of isothiocyanate in food preservation. Food Technol., New York, v. 49, p. 73-84, 1995.

DUPONT, B.; GRAYBILL, J.R.; ARMSTRONG, D. Fungal infection in AIDS patients. J. Med. Vet. Mycol., Chicago, v. 30, p. 19-28, 1992.

EDWARDS, J.R.; FOLLAR, S.G. Current strategies for treating invasive candidiasis: emphasis on infections in nonneutropic patients. Clin. Inf. Dis., Chicago, v. 14, p. 106-113, 1992.

GOMPERTZ, O.F. Características gerais das micoses. In: TRABULSI, L.R.; ALTHERTUM, F.; GOMPERTZ, O.F., (EDS.). Microbiologia. 3. ed. São Paulo: Atheneu, 2002.p.377-388.

HADACEK, F.; GREGER, H. Testing of antifungal natural products: methodologies, comparability of results and essay choose. Phytochem. Ann., Londres, v. 11, p. 137147,2000 .

HAZEN, J.M. New and emerging yeast pathogens. Clin. Microbiol. Rev., Chicago, v. 8, p. 462-478, 1995.

HELANDER, L.M.; ALAKOMI, H.L.; LATVA-KALA, K. Characterization of the action of selected essential oil components on gram-positive bacteria. J. Agric. Food Chem., Columbus, v. 46, p.3590-3595, 1998.
KARAPNAN, M. Inhibitory effect of anethole and eugenol on the growth and toxin production of Aspergillus parasiticus. Int. J. Food Microbiol., Copenhagen, v. 10, p. 193-200, 1990.

KARAPNAN, M.; AKTUG, S.E. Inhibition of foodborne pathogens by thymol, eugenol, mentol and anethole. Int. J. Food Microbiol., Copenhagen, v. 4, n. 161-166, 1987.

MARINO, M.;BERSANI, C.; COMI, G. Impedance measurements to study the antimicrobial activity of essential oil from Lamiaceae and Compositae. Int. J. Food Microbiol., Copenhagen, v. 67, p. 187-195, 2001.

MEUNIER, F.; AOUN, M.; BITAR, N. Candidemia in immunocropromissed patients. Clin. Inf. Dis., Chicago, v. 14, p. 120-125, 1992.

NASCIMENTO, G.G.F.; LOCATELLI, J.; FREITAS, P.C. Antibacterial activity of extracts and phytochemicals on antibiotic-resistant bacteria. Braz. J. Microbiol., São Paulo, v. 31, p. 65-72, 2000.

ODDS, F.C. Antifungal activity of saperconazole (R. 66905) in vitro. J. Antim. Chemother., Oxford, v. 24, p. 533-537, 1989.

STANGARLIN, J.R.; FREITAS, K.R.S.E.; CRUZ, M.E. Plantas medicinais. Biotecnol. Cien. Desenv., São Paulo, v. 2, p. 16-22, 1999.

Recebido para publicação em 31 de janeiro de 2004 Aceito para publicação em 11 de abril de 2005 